\title{
Erratum: MicroRNA gets down to business
}

George S Mack

Nat. Biotechnol. 25, 631-638 (2007); published online 7 June 2007; corrected after print 7 December 2010

In the version of the article originally published, reference 8 incorrectly listed Chang, D.Z. as the first author. It should have read Tsuda, N. The error has been corrected in the HTML and PDF versions of the article.

\section{Erratum: Can cancer clinical trials be fixed?}

\section{Malorye Allison}

Nat. Biotechnol. 29, 13-15 (2011); published online 10 January 2011; corrected after print 9 February 2011

In the version of the article originally published, it was stated that "Avastin was studied in combination with Taxol in all these trials, and compared to Taxol alone." It should have read, "Avastin was studied in combination with chemotherapy." In addition, it stated that the FDA had rescinded approval of Avastin for metastatic breast cancer. It should have read, the FDA "recommended removal of the breast cancer indication from the Avastin label..." The errors have been corrected in the HTML and PDF versions of the article.

\section{Erratum: Haplotype-resolved genome sequencing of a Gujarati Indian} individual

Jacob O Kitzman, Alexandra P MacKenzie, Andrew Adey, Joseph B Hiatt, Rupali P Patwardhan, Peter H Sudmant, Sarah B Ng, Can Alkan, Ruolan Qiu, Evan E Eichler \& Jay Shendure

Nat. Biotechnol. 29, 59-63 (2011); published online 19 December 2010; corrected after print 12 April 2011

In the HTML version of this article initially published online, the web link for accession code SRA026360 was incorrect. This error has been corrected in the HTML version of the article.

\section{Erratum: Gene therapy finds its niche}

\section{Cormac Sheridan}

Nat. Biotechnol. 29, 121-128 (2011); published online 7 February 2011; corrected after print 12 April 2011

In the version of the article originally published, Table 1 left off AAV as a section heading. A number of products listed under Adenovirus should have been listed under AAV. Neurologix product NLXP10 was incorrectly listed under the heading of retrovirus, and in phase 2 of development. It should have been listed under the heading AAV, and the phase of development should have read "phase 2 completed." The errors have been corrected in the HTML and PDF versions of the article.

\section{Addendum: Chinese hamster ovary cells can produce galactose- $\alpha-1$, 3-galactose antigens on proteins}

Carlos J Bosques, Brian E Collins, James W Meador III, Hetal Sarvaiya, Jennifer L Murphy, Guy DelloRusso, Dorota A Bulik, I-Hsuan Hsu, Nathaniel Washburn, Sandra F Sipsey, James R Myette, Rahul Raman, Zachary Shriver, Ram Sasisekharan \& Ganesh Venkataraman Nat. Biotechnol. 28, 1153-1156 (2010); published online 5 November 2010; addendum published after print 12 April 2011

Over the last 20 years, numerous investigations examining the glycosylation of proteins expressed in Chinese hamster ovary (CHO) cells have failed to document the ability of $\mathrm{CHO}$ cells to decorate proteins with galactose- $\alpha-1,3$-galactose ( $\alpha$-Gal) epitopes ${ }^{1-6}$. However, the ability of $\mathrm{CHO}$ cells to produce the $\alpha$-Gal epitope in recombinant proteins was reported before ${ }^{7}$. The mechanism of activation of the $\alpha-(1,3)$-galactosyltransferase in $\mathrm{CHO}$ cells remains unclear. A possible factor may involve the transfection process, as similar activation has been documented with other glycosyltransferases ${ }^{8}$.

1. Jenkins, N., Parekh, R.B. \& James, D.C. Getting the glycosylation right: implications for the biotechnology industry. Nat. Biotechnol. 14, 975-981 (1996).

2. Macher, B.A. \& Galili, U. The Galalpha1,3Galbeta1,4GIcNAc-R (alpha-Gal) epitope: a carbohydrate of unique evolution and clinical relevance. Biochim. Biophys. Acta 1780, 75-88 (2008).

3. Sheeley, D.M., Merrill, B.M. \& Taylor, L.C. Characterization of monoclonal antibody glycosylation: comparison of expression systems and identification of terminal alpha-linked galactose. Anal. Biochem. 247, 102-110 (1997).

4. Beck, A. et al. Trends in glycosylation, glycoanalysis and glycoengineering of therapeutic antibodies and Fc-fusion proteins. Curr. Pharm. Biotechnol. 9, 482-501 (2008).

5. Spellman, M.W., Leonard, C.K., Basa, L.J., Gelineo, I. \& van Halbeek, H. Carbohydrate structures of recombinant soluble human CD4 expressed in Chinese hamster ovary cells. Biochemistry 30, 2395-2406 (1991).

6. Kagawa, Y. et al. Comparative study of the asparagine-linked sugar chains of natural human interferon-beta 1 and recombinant human interferon-beta 1 produced by three different mammalian cells. J. Biol. Chem. 263, 17508-17515 (1988).

7. Ashford, D.A. et al. Site-specific glycosylation of recombinant rat and human soluble CD4 variants expressed in Chinese hamster ovary cells. J. Biol. Chem. 268, 3260-3267 (1993).

8. Potvin, B., Kumar, R., Howard, D.R. \& Stanley, P. Transfection of a human alpha-(1,3)fucosyltransferase gene into Chinese hamster ovary cells. Complications arise from activation of endogenous alpha-(1,3)fucosyltransferases. J. Biol. Chem. 265, 1615-1622 (1990). 